Bangladesh J. Bot. 42(1): 161-165, 2013 (June)

\title{
ESTIMATION OF NITROGEN TRANSFORMING MICROORGANISMS IN SOILS OF DIFFERENT TEA VALLEYS OF BANGLADESH
}

\author{
MA Gafur and Afroza Sultana \\ Department of Botany, University of Chittagong, Chittagong-4331, Bangladesh
}

Key words: Microorganisms, Soils, Tea valleys, Bangladesh

\begin{abstract}
Physico-chemical properties of soils and quantitative estimation and distribution of population of Azotobacter, ammonifying, nitrifying and denitrifying bacteria in soils under tea plants of tea valleys of Bangladesh were studied. Soil texture ranged from loam to clay loam, pH ranged from $4.84-5.65$ and organic carbon varied between 0.18 and 2.12\%. Population of Azotobacter, ammonifying bacteria, Nitrosomonas, Nitrobacter and denitrifying bacteria ranged from $18.0 \times 10^{9} / \mathrm{g}-88.4 \times 10^{9} \mathrm{cfu} / \mathrm{g}$ soil, $0.20 \times$ $10^{9} / \mathrm{g}-0.24 \times 10^{9} / \mathrm{g}$ soil, $0.20 \times 10^{9} / \mathrm{g}-0.24 \times 10^{9} / \mathrm{g}$ soil, $0.20 \times 10^{9} / \mathrm{g}-0.24 \times 10^{9} / \mathrm{g}$ soil and $0.17 \times 10^{9} / \mathrm{g}-$ $0.24 \times 10^{9} / \mathrm{g}$ soil, respectively. The populations of microorganisms were not related with soil $\mathrm{pH}$ and organic carbon. Ammonifying bacteria was positively and significantly correlated with Nitrosomonas and Nitrobacter and Nitrosomonas with Nitrobacter at $0.01 \%$ level.
\end{abstract}

\section{Introduction}

Tea Camellia sinensis (L.) O. Kuntze belongs to Theaceae and its leaves provide worldwide the cheapest and the most popular beverage (Amarakoon 2004). There are 163 tea estates in Bangladesh distributed in Moulovibazar, Habiganj, Chittagong, Sylhet and Panchagar. Small areas in Brahmanbaria and Rangamati have also been planted with tea (Sana 1989).

For a healthy growth and economic production of tea, soil quality determined by its physicochemical properties and biological activities is of primary concern. Soil texture, organic matter and nutrient status are important criteria. Low organic matter and presence of appreciable amount of iron and aluminium in most tea soils of Bangladesh reduce the availability of phosphate to plants (Kibria 1981). Tea soils are usually acidic due to the prolonged use of nitrogenous fertilizer such as urea and ammonium sulphate to obtain high crop production (Ishaque and Cornfield 1974).

For many nutrients poor ecosystems, nutrient cycling brought about by rhizosphere and nonrhizosphere organisms play a vital role. The cycling of organic matter and nutrients in soil provide healthy biochemical environment around roots of tea plants. Coarse to medium textured acidic soils with low fertility status may affect the rate of nitrification, by Nitrosomonas and Nitrobacter. Since a few reports are available on microbial activities in soils under tea plants of Bangladesh and little is known about their nitrogen transforming microbial population of soil under tea plantation, the present investigation was undertaken to study the properties of soil and the population and distribution of Azotobacter, ammonifying, nitrifying and denitrifying bacteria in soils under tea plantations of seven different circles of Sylhet and Chittagong divisions.

\section{Materials and Methods}

Soil samples were collected from different circles with a representative in each circle, namely Balisera, Mono-Doloi, Juri, Lungla, Luskerpure, North-Sylhet and Chittagong (Table 1). Each site was divided into three sub-sites, namely tillah, flat and kunchi. A number of soil samples were collected from each sub-site with an auger at $0-15 \mathrm{~cm}$ depths and mixed in equal proportion to form a composite sample in May, 2011. There were a total of 21 samples. Soil samples were used for physico-chemical analyses and estimation of the nitrogen transforming microorganisms. 
Soil texture was determined by Bouyoucos hydrometer method. Soil pH $(1: 2$ soil water ratios) was measured with a digital $\mathrm{pH}$ meter (TOA Japan). Soil organic carbon was determined by Walkley and Black (1934) wet oxidation method. For the estimation of microbial population soil samples were diluted for a series of dilutions up to $10^{9}$. Azotobacter was cultured in nitrogen free sucrose medium, and ammonifying bacteria in nutrient broth solution (Alexander 1965), Nitrosomonas in ammonium-calcium carbonate medium, Nitrobacter in nitrite-calcium carbonate medium (Alexander and Clark 1965) and denitrifying bacteria in medium for denitrification test. The population was calculated with the help of MPN chart according to Alexander (1965).

\section{Results and Discussion}

The values of the physico-chemical properties of soils appear in Table 1. Soil texture ranged from loam to clay loam in all sampling sites. Clay loam was present in 7 sites, sandy loam in 5 sites, loam in 7 sites, sandy clayey loam and loamy sand in 1 site in each. Sandy loam was maximum in tillah and clay loam in kunchi and flat. Akter (2002) reported similar results of soil texture. The soils were all acidic in reaction. The $\mathrm{pH}$ values ranged from 4.84 - 5.65 which agreed with the reports of Chowdhury (1978), Akter (2002) and Adhikari (2003). Generally the pH of the

Table 1. Physico-chemical properties of soils under different circles of tea plantations in Bangladesh.

\begin{tabular}{|c|c|c|c|c|c|}
\hline Circle & Sampling site & Position & Soil texture & $\mathrm{pH}$ & Org. C (\%) \\
\hline Balisera & Kalighat Tea Estate & Flat & $\mathrm{CL}$ & 5.10 & 0.33 \\
\hline Balisera & Kalighat Tea Estate & Kunchi & SL & 5.17 & 1.30 \\
\hline Balisera & Kalighat Tea Estate & Tillah & SL & 5.15 & 2.12 \\
\hline Chittagong & Oodaleah Tea Estate & Flat & $\mathrm{L}$ & 4.97 & 0.94 \\
\hline Chittagong & Oodaleah Tea Estate & Kunchi & $\mathrm{L}$ & 5.07 & 0.33 \\
\hline Chittagong & Oodaleah Tea Estate & Tillah & SL & 5.33 & 0.68 \\
\hline Juri & New Sumonbag Tea Estate & Flat & CL & 5.17 & 2.04 \\
\hline Juri & New Sumonbag Tea Estate & Kunchi & CL & 5.20 & 0.32 \\
\hline Juri & New Sumonbag Tea Estate & Tillah & SCL & 5.17 & 1.86 \\
\hline Lungla & Gazipur Tea Estate & Flat & $\mathrm{L}$ & 5.65 & 1.91 \\
\hline Lungla & Gazipur Tea Estate & Kunchi & CL & 5.19 & 1.57 \\
\hline Lungla & Gazipur Tea Estate & Tillah & CL & 5.32 & 0.72 \\
\hline Luskerpure & Luskerpure Tea Estate & Flat & $\mathrm{L}$ & 5.30 & 1.06 \\
\hline Luskerpure & Luskerpure Tea Estate & Kunchi & CL & 5.34 & 1.25 \\
\hline Luskerpure & Luskerpure Tea Estate & Tillah & CL & 5.19 & 0.19 \\
\hline Mono-Doloi & Mono-Doloi Tea Estate & Flat & $\mathrm{L}$ & 5.05 & 1.56 \\
\hline Mono-Doloi & Mono-Doloi Tea Estate & Kunchi & $\mathrm{L}$ & 5.20 & 1.23 \\
\hline Mono-Doloi & Mono-Doloi Tea Estate & Tillah & SL & 4.84 & 1.95 \\
\hline North-Sylhet & Malnichara Tea Estate & Flat & LS & 5.04 & 0.18 \\
\hline North-Sylhet & Malnichara Tea Estate & Kunchi & $\mathrm{L}$ & 5.40 & 1.57 \\
\hline North-Sylhet & Malnichara Tea Estate & Tillah & SL & 5.32 & 1.29 \\
\hline
\end{tabular}

$\mathrm{L}=$ Loam, SL = Sandy loam, SCL = Sandy clayey loam, LS = Loamy sand, CL = Clayey loam.

soils in tea growing countries of the world varies from $3.3-6.0$, and a soil $\mathrm{pH} 4.5-5.5$ is considered to be the optimum for the utilization of nutrients especially nitrogen by tea plants (Natesan 1999). The maximum organic carbon was $2.12 \%$ in the tillah of Kalighat Tea Estate followed by $2.04 \%$ in flat of New Sumonbag Tea Estate. The lowest was $0.18 \%$ in flat of 
Malnichara Tea Estate. Organic carbon ranged from 0.18 - 0.94\% in 8 sites, 1.06 - 1.57\% in 8 sites and $1.86-2.12 \%$ in 5 sites. BARC (1989) categorized organic matter in agricultural soils of Bangladesh. According to them, 8 sites fall in the very low, 8 sites fall in low and 5 sites fall in the medium category.

Quantitative estimation of populations of Azotobacter, ammonifying bacteria, Nitrosomonas, Nitrobacter and denitrifying bacteria in surface soils under different selected circles were estimated and are shown in Table 2. The highest Azotobacter population was $88.4 \times 10^{9} \mathrm{cfu} / \mathrm{g}$ soil found in kunchi of Monu-Doloi and the lowest $18.0 \times 10^{9} \mathrm{cfu} / \mathrm{g}$ soil in flat of Monu-Doloi and kunchi of Gazipur Tea Estates. It was observed that Azotobacter population was better in tillah. The present findings corroborate well with Zhang et al. (1988), Hegazi et al. (1979), Ranjana and Nagaraj (1989), Khan and Rahman (2003) and Akond et al. (2006).

Table 2. Population of Azotobacter, ammonifying bacteria (AB), Nitrosomonas (NM), Nitrobacter (NB) and denitrifying bacteria (DB) in soils under different circles of tea plantations in Bangladesh.

\begin{tabular}{llccccc}
\hline \multirow{2}{*}{ Circle } & Position & Azotobacter & AB & NM & NB & DB \\
\cline { 3 - 7 } & & No. of total & MPN $\times$ & MPN \pm & MPN \pm & MPN $\times$ \\
cfu $\times 10^{9} /$ g soil & $10^{9}$ g soil & $10^{9} /$ g soil & $10^{9} / g$ soil & $10^{9}$ g soil \\
\hline Balisera & Flat & 60.5 & 0.24 & 0.24 & 0.24 & 0.24 \\
Balisera & Kunchi & 82.1 & 0.20 & 0.20 & 0.20 & 0.17 \\
Balisera & Tillah & 20.2 & 0.24 & 0.24 & 0.24 & 0.24 \\
Monu-Doloi & Flat & 18.0 & 0.20 & 0.20 & 0.20 & 0.24 \\
Monu-Doloi & Kunchi & 88.4 & 0.24 & 0.24 & 0.24 & 0.24 \\
Monu-Doloi & Tillah & 47.4 & 0.24 & 0.24 & 0.24 & 0.20 \\
Juri & Flat & 40.6 & 0.24 & 0.24 & 0.24 & 0.20 \\
Juri & Kunchi & 34.5 & 0.24 & 0.24 & 0.24 & 0.24 \\
Juri & Tillah & 53.2 & 0.24 & 0.24 & 0.24 & 0.20 \\
Lungla & Flat & 23.5 & 0.24 & 0.24 & 0.24 & 0.20 \\
Lungla & Kunchi & 18.0 & 0.24 & 0.24 & 0.24 & 0.24 \\
Lungla & Tillah & 35.2 & 0.24 & 0.24 & 0.24 & 0.24 \\
Luskerpur & Flat & 25.3 & 0.24 & 0.24 & 0.24 & 0.20 \\
Luskerpur & Kunchi & 38.5 & 0.24 & 0.24 & 0.24 & 0.20 \\
Luskerpur & Tillah & 73.3 & 0.24 & 0.24 & 0.24 & 0.24 \\
North-Sylhet & Flat & 49.5 & 0.24 & 0.24 & 0.24 & 0.17 \\
North-Sylhet & Kunchi & 52.8 & 0.24 & 0.24 & 0.24 & 0.24 \\
North-Sylhet & Tillah & 55.0 & 0.24 & 0.24 & 0.24 & 0.24 \\
Chittagong & Flat & 77.0 & 0.24 & 0.24 & 0.24 & 0.24 \\
Chittagong & Kunchi & 30.1 & 0.24 & 0.24 & 0.24 & 0.24 \\
Chittagong & Tillah & 40.3 & 0.24 & 0.24 & 0.24 & 0.24 \\
\hline
\end{tabular}

The maximum population of ammonifying bacteria was $0.24 \times 10^{9} / \mathrm{g}$ soil observed in 19 sites and the minimum $0.20 \times 10^{9} / \mathrm{g}$ soil in two sites. The findings of the present study agree with Adhikari (2003).

The population of Nitrosomonas varied from $0.20 \times 10^{9} / \mathrm{g}-0.24 \times 10^{9} / \mathrm{g}$ soil. Nineteen sites had the same population of Nitrosomonas. The range of Nitrobacter was similar to that of Nitrosomonas. The highest population of denitrifying bacteria was $0.24 \times 10^{9} / \mathrm{g}$ soil and the lowest was $0.17 \times 10^{9} / g$ soil. The above findings agreed with Begum (2001) and Adhikari (2003). 
Statistical analyses showed (Table 3) that a significant variation existed between population of ammonifying bacteria and that of Nitrosomonas, ammonifying bacteria and Nitrobacter, and Nitrosomonas and Nitrobacter. Ammonifying bacteria was positively and significantly correlated with Nitrosomonas and Nitrobacter at $0.1 \%$ level. Again Nitrosomonas was positively and significantly correlated with Nitrobacter at $0.1 \%$ level. These findings conform well with Mai (1988) and Jha et al. (1996). No variation was observed among soil and microbial population but Martyniuk et al. (2002) reported that significant correlation between numbers of Azotobacter spp. and the contents of organic $\mathrm{C}$ in the Polish soils indicated that soil fertility is an important factor for colonization of soils by Azotobacter.

Table 3. Relationships among soil properties and microorganisms of soils under different circles of tea plantations in Bangladesh.

\begin{tabular}{lcccccc}
\hline & $\begin{array}{c}\text { Organic } \\
\text { carbon }\end{array}$ & $\begin{array}{c}\text { Azoto- } \\
\text { bacter }\end{array}$ & $\begin{array}{c}\text { Ammonifying } \\
\text { bacteria }\end{array}$ & $\begin{array}{c}\text { Nitroso- } \\
\text { monas }\end{array}$ & $\begin{array}{c}\text { Nitro- } \\
\text { bacter }\end{array}$ & $\begin{array}{c}\text { Denitrifying } \\
\text { bacteria }\end{array}$ \\
\hline $\mathrm{pH}$ & 0.128 & -0.175 & 0.251 & 0.251 & 0.251 & 0.134 \\
Organic carbon & - & -0.72 & 0.022 & 0.022 & 0.022 & -0.091 \\
Azotobacter & - & - & -0.065 & -0.065 & -0.065 & -0.065 \\
Ammonifying bacteria & - & - & - & $1.000^{* *}$ & $1.000^{* *}$ & 0.199 \\
Nitrosomonas & - & - & - & - & $1.000^{* *}$ & 0.199 \\
Nitrobacter & - & - & - & - & - & 0.199 \\
\hline
\end{tabular}

**Correlation is significant at the $0.01 \%$ level (1-tailed).

\section{Acknowledgement}

The authors acknowledge the assistance of Professor Dr. K. T. Osman, Department of Soil Science and Dean, Faculty of Biological Sciences, University of Chittagong in the preparation of the manuscript.

\section{References}

Adhikari NM 2003. Studies on nitrogen transforming microorganisms in soils of different tea estates of Srimangal. M. Sc. Thesis, Department of Botany, University of Chittagong, Bangladesh. pp. 74.

Akond MA, Mubassara S and Rahman MM 2006. Distribution and abundance of Azotobacter in wheat fields of Bangladesh. Bangladesh J. Microbiol. 24(2): 151-153.

Akter S 2002. Distribution of BGA and Azotobacter in soils under tea plants of Oodaleah Tea Estate, Chittagong. M. Sc. Thesis, Department of Botany, University of Chittagong, Bangladesh. pp. 78.

Alexander M 1965. Most probable number method for microbial population. In: Methods of Soil Analysis, C. A. Black (ed.). Madison, Wisc: Am. Soc. Agron. pp. 1467-1472.

Alexander M and Clark FE 1965. Nitrifying bacteria. In: Methods of Soil Analysis. CA Black (ed.). Am. Soc. Agron. Madison, Wisconsin. pp.1477-1483.

Ammarakoon AMT 2004. Tea for health. Published in Tea Research Institute of Sri Lanka. pp. 38

BARC (Bangladesh Agricultural Research Council) 1989. Fertilizer Recommendation Guide. Bangladesh Agricultural Research Council. Soil Pub. 32: pp. 130.

Begum M 2001. Studies on the microorganisms in soils of different forest tree species at Chittagong University Campus. M. Sc. Thesis. Department of Botany, University of Chittagong. pp. 85.

Chowdhury SH 1978. Status of nitrogen and rate of added nitrogen in tea soils of Bangladesh. Tea Journal of Bangladesh.. 14(1): 2-11.

Hegazi NA, Edi M, Frag RS and Monib M. 1979. Asymbiotic nitrogen fixation in the rhizosphere of sugarcane planted under semi-arid condition of Egypt. Rev. Ecol. Biol. Sci. 16(1): 23-37. 
Ishaque M and Cornfield AH 1972. Nitrogen mineralization and nitrification during incubation of East Pakistan tea soils in relation to $\mathrm{pH}$. Plant and Soil 37: 91-95.

Jha PB, Singh JS and Kashyap AK 1996. Dynamics of viable nitrifier community and nutrient availability in dry tropical forest habitat as affected by cultivation and soil texture. Plant and Soil 180: 277-285.

Khan ZUM and Rahman F 2003. Distribution of heterotrophic bacteria and Azosporillum in sandy lands. Bangladesh J. Life Sci. 15(1): 13-16.

Kibria AKMG 1981. Rock phosphate. A potential fertilizer of tea. Tea Journal of Bangladesh. 17(1\&2): 3537.

Mai H. 1988. Nitrification in raw humus under Norway spruce stands. Zentralblatt fur Mikrobiologie. 143: 229-237.

Martyniuk S and Martyniuk M 2002. Occurrence of Azotobacter spp. in some Polish soils. Polish J. Environ. Stud. 12(3): 371-374.

Natesan S 1999. Tea Soil. In: Global Advances in Tea Science. N.K. Jain (ed.). Aravali Books International Pvt. Ltd., New Delhi. pp. 519-532.

Ranjana N and Nagaraj R 1989. Occurrence of Azotobacter and Beijerinckia in forest soils of Maharashtra. Indian J. For. 12(2): 112-116.

Sana DL 1989. Tea Science. Ashrafi Boi Ghar. Dhaka, Bangladesh. pp. 272.

Walkley A and Black IA 1934. An examination of the Detjeraff method for determining soil organic matter and a proposed modification of the chromic acid titration method. Soil Sci. 37: 29-38.

Zhang DH, Yang YS, Wu ZX and Li ZW 1988. A preliminary study of the microflora in soils and soil fertility in the stands of Pinus massoniana mixed with Schima superba. For. Sci. and Tech. 9: 6-8.

(Manuscript received on 10 April, 2013; revised on 1 June, 2013) 